\title{
Biodegradation of BTEX in a fungal biofilter: Influence of operational parameters, effect of shock-loads and substrate stratification
}

Eldon R. Rene, Balsam T. Mohammad, María C. Veiga, Christian Kennes

Bioresource Technologye, Volume 116, 2012, Pages518-22

DOI: 10.1016/j.biortech.2011.12.006

\section{Abstract}

The effect of relative humidity (RH: $30 \%$ to $>95 \%$ ) of a gas-phase mixture composed of benzene, toluene, ethylbenzene and para-, meta- and ortho-xylenes (BTEX), inlet concentrations (0.2-12.6 $\mathrm{g} \mathrm{m}^{-3}$ ), and empty bed residence times (EBRTs) (48-144 s) was tested in a fungi-dominant biofilter. A maximum elimination capacity $\left(\mathrm{EC}_{\max }\right)$ of 244.2 gBTEX m$^{-3} \mathrm{~h}^{-1}$ was achieved at a total inlet loading rate (ILR ${ }_{\mathrm{T}}$ of 371.2 gBTEX m ${ }^{-3} \mathrm{~h}^{-1}$ (RH: 65\%). The transient-state response was tested by increasing the ILR $_{\mathrm{T}}$, in two steps, from $\sim 50$ to $850 \mathrm{~g} \mathrm{~m}^{-3} \mathrm{~h}^{-1}$ and from $\sim 50$ to $320 \mathrm{~g} \mathrm{~m}^{-3} \mathrm{~h}^{-1}$, at a constant EBRT of $41.7 \mathrm{~s}$. Increasing the $\mathrm{ILR}_{\mathrm{T}}$ reduced the total BTEX removal efficiency $\left(\mathrm{RE}_{\mathrm{T}}\right)$ from $>97 \%$ to $35 \%$, and from $>90 \%$ to $60 \%$ during medium and high shock-load, respectively. When subjected to short (4 d) and long-term (7 d) shut-down periods, the biofilter was able to recover high $\mathrm{EC}_{\max }$ of, respectively, 200 and 72 gBTEX $\mathrm{m}^{-} 3 \mathrm{~h}^{-1}$ after resuming operation.

\section{Keywords}

Fungi; Relative humidity; pH; Gas to liquid (G/L) ratio; Transient-operations.

\section{Introduction}

Benzene, toluene, ethylbenzene, para, meta, and ortho-xylenes, collectively called BTEX, are important industrial chemicals and are well-known volatile organic compounds (VOCs) of environmental and health concern. Due to improper handling and disposal practices, and the negligence or failure of some process industries to adopt suitable VOC elimination techniques, these compounds can frequently be released into the ambient atmosphere.

Biofilters allow the treatment of low concentrations of contaminants, at high gas-flow rates. In a biofilter, the attached microorganisms convert the gas-phase pollutant(s) into end-products such as carbon dioxide, water, biomass and salts. Recent studies have even successfully evaluated the possibility of converting some volatile pollutants to useful products such as biofuels (Abubackar et al., 2011). The extent to which biological waste-gas purification can occur in a biofilter is affected by several factors: physical and chemical properties of the pollutant(s), degree of biodegradability of the pollutant(s), pollutant loading rate, microbial physiology and ecology, and other suitable environmental conditions such as temperature, relative humidity (RH), and $\mathrm{pH}$ (Kennes and Veiga, 2001 and Jorio et al., 2009). Literature reports on the removal of BTEX compounds in fungi-inoculated or fungi-dominant biofilters are sparse, though a few 
authors have investigated the removal of BTX or BTEX compounds, as mixtures, in liquid systems using fungi (Oh et al., 1994 and Prenafeta-Boldu et al., 2002). One of the main advantages of favouring the growth of fungi rather than bacteria for the removal of hydrophobic pollutants in biofilters is their ability to degrade these compounds under a broad range of process conditions (Kennes and Veiga, 2004).

Most of the reported studies on the biofiltration of BTEX (B, T, E, $p-\mathrm{X}, m-\mathrm{X}$ and $o-\mathrm{X}$ compounds) were carried out at steady-state. The transient-state behavior of waste-gas treatment systems to sudden variations in operating conditions, during shock-loads or shut-down and re-start operation, has started to receive attention and there are several recent studies that have reported transient behavior with a single pollutant. In field applications, the occurrence of transient conditions, either in the form of an unexpected pollutant shock-load, or complete reactor shut-down, can be either regular or frequent ( Seignez et al., 2004 and Moe and Li, 2005). Such transient operations would lead to instability of the biomass, perturbation between steady-states and would eventually affect the dynamics of pollutant removal and reaction kinetics in the waste-gas treatment system. Substrate starvation is also a type of shock-load where no external substrate is fed to the microbial population, thus depriving them of the essential carbon and energy source. Pollutant starvation can be expected in process industries under the following conditions: overnight or weekend closures, plant maintenance, equipment malfunctioning, and regular change in process operation ( Nabatilan et al., 2010). Reacclimation times after starvation for a biofilter can vary widely depending on the starvation period, pollutant characteristics, microbial activity, packing material, and reactor configuration, among others. A prior knowledge on the re-acclimation times after shut-down of biological waste-gas treatment systems can be important from both design and performance view-point ( Qi and Moe, 2006).

In a previous work, Mohammad et al. (2007) investigated gas-phase BTEX removal in a perlite biofilter that reached a maximum elimination capacity $\left(\mathrm{EC}_{\max }\right)$ of $188 \mathrm{gBTEX} \mathrm{m}^{-3} \mathrm{~h}^{-1}$ with $62 \%$ removal efficiency (RE), over $212 \mathrm{~d}$ of continuous operation. The dominant microorganism in that biofilter was identified as being a fungal

Exophiala species, a dark gray pigmented dimorphic hyphomycete, which was isolated later from the reactor. In an attempt to strengthen our research understanding with fungal bioreactors, this study was undertaken with the following objectives: (i) to evaluate the performance of the biofilter at different EBRTs (144 and $48 \mathrm{~s}$ ) at RH values $>95 \%$, (ii) to study the biofilter's performance at different RH values of $65 \%, 45 \%$ and $30 \%$, at a constant EBRT, (iii) to identify the effect of maintaining different $\mathrm{pH}$ conditions in the filter bed, i.e., 5.9, 7.0 and 4.9, by continuously trickling a constant $\mathrm{pH}$ nutrient medium, (iv) to examine the response of the biofilter to high/medium shockloads of BTEX by increasing their individual concentrations from low to high levels, (v) to examine the recovering capacity of the biofilter after short and long-term shut-down periods, and (vi) to monitor the BTEX stratification profiles along the biofilter height.

\section{Methods}

\subsection{Microorganisms and media composition}

The mesophilic biofilter was originally inoculated with a mixed culture taken from refinery sludge (Mohammad et al., 2007). During continuous biofilter operation, at RH $>95 \%$, and at an EBRT of $96 \mathrm{~s}$, it was observed that fungi, mainly an Exophiala sp., 
became dominant, although some bacteria were also present. A well-defined mineral salt medium having the following chemical composition (per liter in distilled water) was used in all the experiments: $0.5 \mathrm{~g} \mathrm{~K}_{2} \mathrm{HPO}_{4}, 0.1 \mathrm{~g} \mathrm{MgSO}_{4} \cdot 7 \mathrm{H}_{2} \mathrm{O}, 4.5 \mathrm{~g} \mathrm{KH}_{2} \mathrm{PO}_{4}, 2 \mathrm{~g}$ $\mathrm{NH}_{4} \mathrm{Cl}$, and $2 \mathrm{~mL}$ of vitamins and trace minerals solution (Kennes et al., 1996). The pH of this medium was 5.9. The medium was autoclaved at $120^{\circ} \mathrm{C}$ for 20 min before adding the filter-sterilized solutions of vitamins and trace minerals. The Exophiala sp., isolated from the reactor, was later grown with gas-phase toluene as the sole carbon

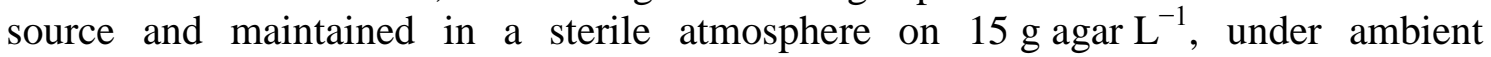
conditions in a desiccator.

\subsection{Biofilter set-up and experiments}

The specifications of the perlite biofilter used in this study were the same as described in a previously published work of our research group (Mohammad et al., 2007). Briefly stating, the biofilter was made of glass having an internal diameter of 10 and $70 \mathrm{~cm}$ in height. The operating volume of the biofilter was $4 \mathrm{~L}$, and sieved perlite (4-6 mm diameter) was used as the packing material. A perforated Teflon mesh was provided at the bottom to act as a support for the packing material, while another perforated mesh at the top acted as a distributor for gas-phase pollutant flow and mineral medium distribution. Gas sampling ports ( 0 - inlet, $1-20 \mathrm{~cm}, 2-40 \mathrm{~cm}$, and 3 - outlet) sealed with rubber septa were available at equal intervals $(20 \mathrm{~cm})$ along the biofilter height.

To generate the BTEX vapors, compressed air was split into two portions, where the major portion of dry air was humidified in a humidification unit placed in a water bath, adjusted to $37^{\circ} \mathrm{C}$ or at lower temperatures $\left(20-30^{\circ} \mathrm{C}\right)$, to maintain the desired air's relative humidity. The minor air stream was bubbled through liquid BTEX in a flask to generate the contaminated air stream. The two streams were then mixed in a mixing unit and fed from the top of the reactor in a down-flow mode. In order to maintain adequate nutrients and moisture contents within the filter bed, liquid medium was sprinkled periodically, once every $3 \mathrm{~d}$, from the top of the biofilter, as would usually be done in full-scale systems.

For experiments involving different $\mathrm{pH}$ levels in the filter bed (5.9, 7.0 and 4.9), the nutrient medium, stored in a continuously stirring nutrient hold tank (Vol - $1.5 \mathrm{~L}$ ), was continuously fed to the biofilter using a peristaltic pump (Watson and Marlow, USA) at a rate of $72 \mathrm{~mL} \mathrm{~min}{ }^{-1}$. Both the nutrient medium and the gas-phase pollutants were thus fed co-currently to the reactor in a down-flow mode. The gas to liquid $(\mathrm{G} / \mathrm{L})$ ratio was maintained between 43 and 125.6 in these experiments. The $\mathrm{pH}$ of the recirculated nutrient medium was maintained constant, at 5.9, 7.0, or 4.9, depending on the experiment, by adding a $2 \mathrm{~N} \mathrm{NaOH}$ solution to neutralize the acidic metabolites formed during the biodegradation process. The $\mathrm{pH}$ was measured by means of a $\mathrm{pH}$ electrode (EASYFERM 120, Hamilton) attached to the nutrient collection tank and an on-line $\mathrm{pH}$ controller coupled to an electro valve (DO 9765T, Dual 31/2 Digit pH redox indicator and regulator, Italy).

The performance of the biofilter was evaluated using the following parameters, defined elsewhere (Kennes et al., 2009a): total BTEX removal efficiency $\left(\mathrm{RE}_{\mathrm{T}}, \%\right.$ \%), total inlet loading rate $\left(\mathrm{ILR}_{\mathrm{T}}, \mathrm{g} \mathrm{m}^{-} 3 \mathrm{~h}^{-1}\right)$ and the total elimination capacity of the biofilter $\left(\mathrm{EC}_{\mathrm{T}}\right.$, $\mathrm{g} \mathrm{m}^{-3} \mathrm{~h}^{-1}$ ). Steady-state biofiltration experiments were carried out by varying the flow rates of the BTEX vapors and humidified air independently to get different initial 
concentrations and EBRTs (30-144 s) in the biofilter. The different biofiltration experiments performed in this study are summarized in Table 1, showing the different EBRTs and ILRs tested.

Table 1.

Experimental scheme of biofilter operation for gas-phase BTEX removal.

\begin{tabular}{|c|c|c|c|c|}
\hline $\begin{array}{l}\text { Nature } \\
\text { experiment }\end{array}$ & ${ }^{\text {of }}$ EBRT, & $\begin{array}{l}\text { Range } \\
\mathbf{g ~ m}^{-3} \mathbf{h}^{-1}\end{array}$ & of & $\begin{array}{l}\text { ILR, Range } \\
\qquad \mathbf{g ~ m}^{-3} h^{-1}\end{array}$ \\
\hline
\end{tabular}

1. Effect of relative humidity $(\mathrm{RH})$

$\begin{array}{llll} & 144 & 47-315 & 46-249 \\ \text { RH: }>95 \% & 96 & 8.1-354 & 2.6-214 \\ & 48 & 37-315 & 22.5-176 \\ \text { RH: } 65 \% & 96 & 19-371.2 & 14.5-244.2 \\ \text { RH: } 45 \% & 96 & 25.1-272.6 & 16.8-221.0 \\ \text { RH: } 30 \% & 96 & 80.4-267 & 54.2-168.8\end{array}$

2. Effect of medium $p H$

\begin{tabular}{lllll}
$\mathrm{pH}$ & $\mathrm{G} / \mathrm{L}$ ratio & \multicolumn{3}{l}{ EBRT, s Range of ILR, $\mathrm{g} \mathrm{m}^{-3} \mathrm{~h}^{-1}$ Range of EC, $\mathrm{g} \mathrm{m}^{-3} \mathrm{~h}^{-1}$} \\
& 43 & 77.8 & $34.9-460.5$ & $16.1-322.2$ \\
5.9 & 80.2 & 41.7 & $48.8-1051.3$ & $37.4-576.4$ \\
& 83.7 & 45 & $63.9-791.2$ & $57.1-638.4$ \\
7.0 & 125.6 & 30 & $29.1-730.5$ & $29-687.8$ \\
& 83.7 & 45 & $147.5-364.1$ & $146.1-357.2$ \\
4.9 & 125.6 & 30 & $181.2-232.8$ & $168.1-208.7$
\end{tabular}

During shock-load, shut-down and re-start experiments, the EBRT was maintained constant at $41.7 \mathrm{~s}$, while the air's $\mathrm{RH}$ was maintained at $>95 \%$ during transient-state experiments. The concentrations of individual BTEX were increased from low to high levels, corresponding to $\mathrm{ILR}_{\mathrm{T}}$ varying between 48.8 and $853.6 \mathrm{gBTEX} \mathrm{m}^{-3} \mathrm{~h}^{-1}$ during shock-load experiments, and between 0 and 257.7 gBTEX m$~^{-3} \mathrm{~h}^{-1}$ during shut-down (short-term $-4 \mathrm{~d}$ and long-term $-7 \mathrm{~d}$ ) experiments, according to the details provided in Table 2. Substrate stratification profiles of individual B, T, E, $p-\mathrm{X}, m-\mathrm{X}$ and $o-\mathrm{X}$ compounds were measured along the filter bed height at $\mathrm{pH}$ 7.0. 
Table 2.

Experimental scheme of biofilter operation for gas-phase BTEX removal under transient-state conditions.

I- During successive shock load tests

\begin{tabular}{lllllll} 
Individual VOCs & $\mathrm{B}$ & $\mathrm{T}$ & $\mathrm{E}$ & $p-\mathrm{X}$ & $m-\mathrm{X}$ & $o-\mathrm{X}$ \\
Concentration & range, $0.07-$ & $0.14-$ & $0.06-$ & $0.09-$ & $0.08-$ & $0.03-$ \\
$\mathrm{g} \mathrm{m}^{-3}$ & 3.92 & 1.3 & 1.25 & 2.3 & 1.43 & 1.06 \\
Range of REs, \% $^{-13-95}$ & $36-100$ & $23-92$ & $31-100$ & $46-100$ & $16-100$ \\
$\mathrm{ILR}_{\max }, \mathrm{g} \mathrm{m}^{-3} \mathrm{~h}^{-1}$ & 338.7 & 112.5 & 108.3 & 205.2 & 123.4 & 91.7 \\
$\mathrm{EC}_{\max }, \mathrm{g} \mathrm{m}^{-3} \mathrm{~h}^{-1}$ & 73.7 & 71.6 & 63.3 & 105.6 & 61.6 & 20.9 \\
Other parameters & \multicolumn{6}{l}{ EBRT $=41.7 \mathrm{~s}, \mathrm{RH}:>95 \%, \mathrm{EC}_{\mathrm{T}}=322.4 \mathrm{~g} \mathrm{~m}^{-3} \mathrm{~h}^{-1}$}
\end{tabular}

II - During shut-down and re-start operations

\begin{tabular}{|c|c|c|c|c|c|c|}
\hline Individual VOCs & B & $\mathrm{T}$ & $\mathrm{E}$ & $p-X$ & $m-\mathrm{X}$ & $o-\mathrm{X}$ \\
\hline $\begin{array}{l}\text { Concentration } \\
\mathrm{g} \mathrm{m}^{-3}\end{array}$ & range, $0-0.7$ & $0-0.5$ & $0-0.6$ & $0-0.7$ & $0-0.4$ & $0-0.2$ \\
\hline Maximum REs,\% & 85.9 & 95.2 & 96.7 & 88.4 & 89.8 & 90.4 \\
\hline $\mathrm{ILR}_{\max }, \mathrm{g} \mathrm{m}^{-3} \mathrm{~h}^{-1}$ & 63.2 & 45.5 & 54.1 & 60.2 & 36.6 & 22.1 \\
\hline $\mathrm{EC}_{\max }, \mathrm{g} \mathrm{m}^{-3} \mathrm{~h}^{-1}$ & 32.5 & 39.8 & 47.9 & 53.2 & 28.3 & 14.5 \\
\hline Other parameters & EBRT & $41.7 \mathrm{~s}$ & $\mathrm{H}:>9$ & $\mathrm{EC}_{\mathrm{T}}=$ & 03.3 & ${ }^{-3} \mathrm{~h}^{-1}$ \\
\hline
\end{tabular}

Note: RE - removal efficiency; ILR - inlet loading rate; EC - elimination capacity

\subsection{Analytical methods}

Gas samples collected from the inlet and outlet of the biofilter were analyzed for residual gas phase $\mathrm{BTE}, m, p \mathrm{X}$ concentrations on a HP 5890 gas chromatograph equipped with a FID, fitted with a $50 \mathrm{~m}$ TRACER column and at $250{ }^{\circ} \mathrm{C}$. The flow rates were $30 \mathrm{~mL} \mathrm{~min}^{-1}$ for $\mathrm{H}_{2}$ and $300 \mathrm{~mL} \mathrm{~min}^{-1}$ for air. Helium was used as carrier gas at a flow rate of $2 \mathrm{~mL} \mathrm{~min}^{-1}$. The initial temperature was $60^{\circ} \mathrm{C}$, followed by heating at a rate of $28^{\circ} \mathrm{C} \min ^{-1}-80^{\circ} \mathrm{C}$, then heating at $18^{\circ} \mathrm{C} \mathrm{min}^{-1}$ to a final temperature of $96{ }^{\circ} \mathrm{C}$. Two milliliter of gas samples were collected, using gastight syringes (Hamilton, Reno, USA), from sampling ports located at the inlet and outlet of the biofilter. Typical gas elution times in the GC were 7.2, 10.5, 14.6, 15.2, 15.6 and 18.5 min, respectively, for individual BTEo,m,pX compounds. $\mathrm{CO}_{2}$ was analyzed with a HP 5890 gas chromatograph equipped with a TCD. The injection and oven temperatures were 90 and $25^{\circ} \mathrm{C}$, respectively, with the TCD set at $100^{\circ} \mathrm{C}$. A glass U-tube water manometer having an operation range of $0-40 \mathrm{~cm}$ was used to periodically monitor the pressure drop across the filter bed height. Moisture content (\%) of the filter bed was periodically measured according to the procedure outlined by Mohammad et al. (2007). The relative humidity of the incoming pollutant-air mixture was monitored using a hand held thermo-hygrometer, Model C210 fitted with a flexible sampling probe (G. Lufft Messund Regeltechnik, GmbH, Germany). 


\section{Results and discussion}

\subsection{Performance at different EBRTs}

Steady-state experiments at three different EBRTs, i.e. , 144, 96 and $48 \mathrm{~s}$, were performed by maintaining the $\mathrm{RH}$ at $>95 \%$, and by increasing the concentration of individual BTEX compounds gradually from low to high values ( Table 1). The total BTEX concentration ( $\mathrm{C}_{\text {inBTEX }}$ CinBTEX) was thus increased from 1.9 to 12.6, 0.2 to 9.4, and 0.5 to $4.2 \mathrm{~g} \mathrm{~m}^{-3}$ at EBRTs of 144, 96, and $48 \mathrm{~s}$, respectively. During this study, the total BTEX inlet loading rate (ILR $)$ varied from 8.1 to $354 \mathrm{~g} \mathrm{~m}^{-3} \mathrm{~h}^{-1}$. At an EBRT of $144 \mathrm{~s}$, for BTEX concentrations below $9 \mathrm{~g} \mathrm{~m}^{-3}$, more than $85 \%$ total BTEX removal $\left(\mathrm{RE}_{\mathrm{T}}\right)$ was noticed $\left(\mathrm{ILR}_{\mathrm{T}}<230 \mathrm{~g} \mathrm{~m}^{-3} \mathrm{~h}^{-1}\right)$. However, for loads exceeding 300 gBTEX m ${ }^{-3} \mathrm{~h}^{-1}$, the performance of the biofilter gradually levelled off and a maximum total elimination capacity $\left(\mathrm{EC}_{\mathrm{T}}\right)$ of $200 \mathrm{~g} \mathrm{~m}^{-3} \mathrm{~h}^{-1}$ (occasionally $250 \mathrm{~g} \mathrm{~m}^{-3} \mathrm{~h}^{-1}$ ) was reached ( Fig. 1a). During biofilter operation at an EBRT of $48 \mathrm{~s}$, the

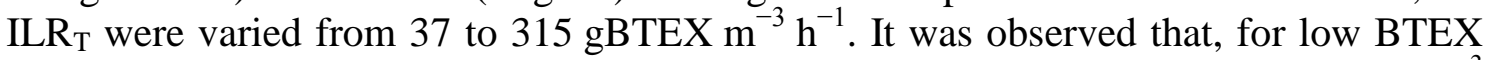
concentrations the RE was close to $100 \%$. For inlet concentrations close to $2 \mathrm{~g} \mathrm{~m}^{-3}$ $\left(\mathrm{ILR}_{\mathrm{T}}\right.$ of $150 \mathrm{gBTEX} \mathrm{m}^{-3} \mathrm{~h}^{-1}$ ), the $\mathrm{RE}_{\mathrm{T}}$ were only about $68 \%$. A further increase in $\mathrm{ILR}_{\mathrm{T}}$ during this phase, decreased the BTEX removal significantly, with about $50 \%$ removal at an $\operatorname{ILR}_{\mathrm{T}}$ close to $300 \mathrm{gBTEX} \mathrm{m}^{-3} \mathrm{~h}^{-1}$ ( Fig. 1a). This decrease in $\mathrm{RE}_{\mathrm{T}}$ could be attributed to insufficient contact time between the gas-phase pollutant and the biofilm. Substrate toxicity, competitive inhibition, and the formation of toxic intermediates by non-specific enzymes may also be responsible for the poor $\mathrm{RE}_{\mathrm{T}}$ at high concentrations of BTEX ( Bielefeldt and Stensel, 1999). More details concerning the biofilter operation at an EBRT of $96 \mathrm{~s}$ can be found in Mohammad et al. (2007). The results are summarized in Fig. 1a, showing that the biofilter performance at $96 \mathrm{~s}$ was something intermediate between the performances at 48 and $144 \mathrm{~s}$. Fig. 1a shows a near linear relation between $\mathrm{ILR}_{\mathrm{T}}$ and $\mathrm{EC}_{\mathrm{T}}$, at different EBRTs up to an inlet load of at least 140 gBTEX m ${ }^{-3} \mathrm{~h}^{-1}$. However, for higher ILR $_{\mathrm{T}}$ tested at the three EBRTs, the EC increased at a slower rate, becoming nearly constant at inlet loads beyond 200 gBTEX $\mathrm{m}^{-3} \mathrm{~h}^{-1}$. This clearly shows the existence of two different operating regimes, as previously described in the literature ( Jorio et al., 2009 and Kennes and Veiga, 2001), i.e. the diffusion limitation regime (DLR) and the reaction limitation regime (RLR): (i) under DLR, for $\mathrm{ILR}_{\mathrm{T}}<140 \mathrm{gBTEX} \mathrm{m}^{-3} \mathrm{~h}^{-1}$, the $\mathrm{EC}_{\mathrm{T}}$ increased linearly with an increase in $\operatorname{ILR}_{\mathrm{T}}$ because the gas-biofilm interface is relatively small and complete mineralization of BTEX occurred in the fungi-dominant biofilm, and (ii) under RLR, when the ILR was $>140$ gBTEX m$^{-3} \mathrm{~h}^{-1}$, the $\mathrm{EC}_{\mathrm{T}}$ remained almost constant and decreased slightly depending on the EBRT. In RLR, the biofilm is fully active and the $\mathrm{RE}_{\mathrm{T}}$ of BTEX is controlled only by the rate of biodegradation. The critical $\mathrm{ILR}_{\mathrm{T}}$ to achieve $>90 \% \mathrm{RE}_{\mathrm{T}}$ (ILR T,critical $_{\text {) }}$, at EBRT of 144, 96, and $48 \mathrm{~s}$, were found to be around 225, 191, and 148 gBTEX m ${ }^{-3} \mathrm{~h}^{-1}$, respectively. The results corroborate some of the literature findings, as the critical load in biological waste-gas treatment systems have shown to decrease with an increase in the gas-flow rate, i.e., decreasing EBRTs ( Kennes and Veiga, 2001). The maximum EC $\mathrm{EC}_{\mathrm{T}}$ was $249 \mathrm{~g} \mathrm{~m}^{-3} \mathrm{~h}^{-1}$, achieved at an $\mathrm{ILR}_{\mathrm{T}}$ of 285 gBTEX m ${ }^{-3} \mathrm{~h}^{-1}$ with $85 \% \mathrm{RE}_{\mathrm{T}}$, when experiments were performed at an EBRT of $144 \mathrm{~s}$. 

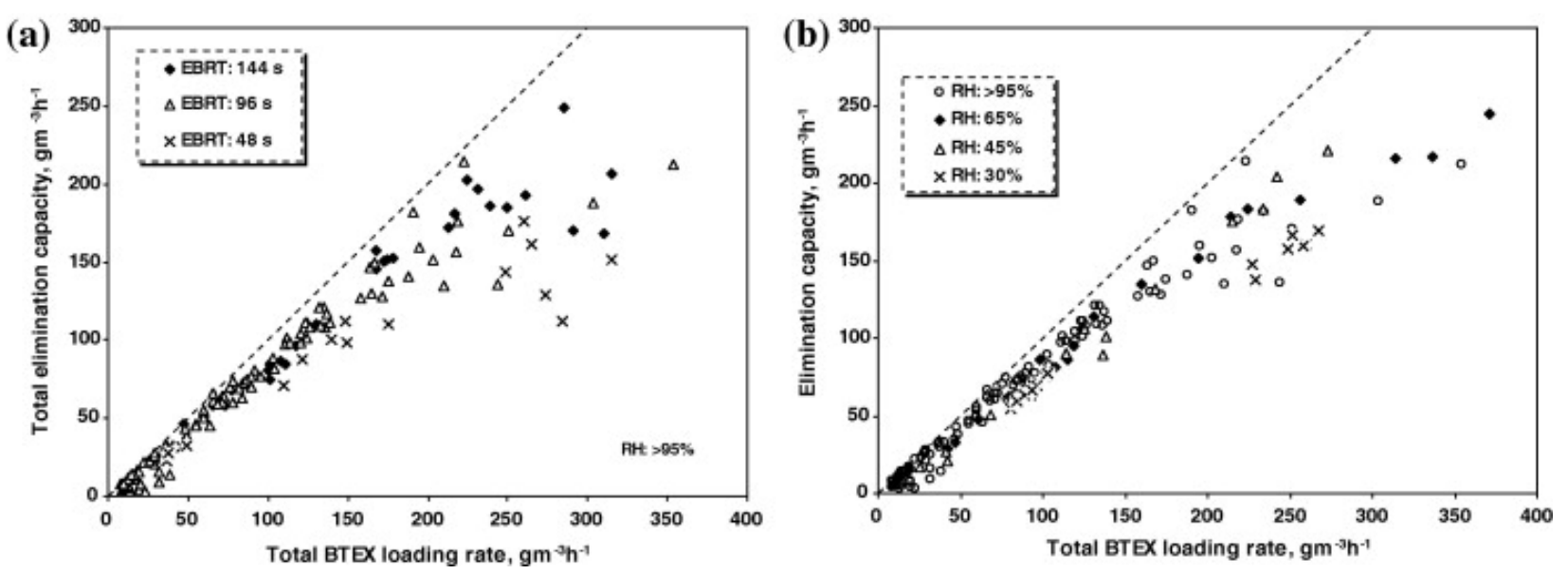

Fig. 1.

Effect of total $\mathrm{ILR}_{\mathrm{T}}$ on the $\mathrm{EC}_{\mathrm{T}}$ of the biofilter at different operating conditions:

(a) EBRTs, and (b) RH.

\subsection{Performance at different RH}

In order to understand the influence of the relative humidity (RH, \%) of the incoming BTEX-polluted air on the pollutant removal characteristics in the biofilter, experiments were performed at three different $\mathrm{RH}$ values of 65,45 , and $30 \%$, at a constant EBRT of $96 \mathrm{~s}$. Maintaining the EBRT at $96 \mathrm{~s}$ allowed a comparison of the biofilter performance with the results obtained in another previous study at a $\mathrm{RH}$ of $>95 \%$. The concentrations of individual BTEX were varied as follows: $\mathrm{B}=0.01-1.2 \mathrm{~g} \mathrm{~m}^{-3}, \mathrm{~T}=0.2-4 \mathrm{~g} \mathrm{~m}^{-3}$, $\mathrm{E}=0.06-2.6 \mathrm{~g} \mathrm{~m}^{-3}, \quad p-\mathrm{X}=0.05-1.9 \mathrm{~g} \mathrm{~m}^{-3}, \quad m-\mathrm{X}=0.04-3 \mathrm{~g} \mathrm{~m}^{-3}, \quad$ and $o-\mathrm{X}=0.03-$ $2.1 \mathrm{~g} \mathrm{~m}^{-3}$. The $\mathrm{ILR}_{\mathrm{T}}$ was varied from 19 to $371.2 \mathrm{gBTEX} \mathrm{m}^{-3} \mathrm{~h}^{-1}$ during the $90 \mathrm{~d}$ experimental study. Fig. 1b compares the effect of $\mathrm{ILR}_{\mathrm{T}}$ on the $\mathrm{EC}_{\mathrm{T}}$ of the biofilter at different $\mathrm{RH}$, including the ones previously obtained at $>95 \% \mathrm{RH}$. It is evident from Fig. 1b that the total BTEX elimination capacity $\left(\mathrm{EC}_{\mathrm{T}}\right)$ increased linearly with an increase in the $\mathrm{ILR}_{\mathrm{T}}$, up to $\sim 200 \mathrm{gBTEX} \mathrm{m}^{-3} \mathrm{~h}^{-1}$, and after that, an increase in the $\mathrm{ILR}_{\mathrm{T}}$ slowed down the rate of increase in $\mathrm{EC}_{\mathrm{T}}$ values. The $\mathrm{EC}_{\mathrm{T}}$ stabilized between 135 and $244 \mathrm{~g} \mathrm{~m}^{-3} \mathrm{~h}^{-1}$ for $\operatorname{ILR}_{\mathrm{T}}>210 \mathrm{gBTEX} \mathrm{m}^{-3} \mathrm{~h}^{-1}$. Thus, for $\operatorname{ILR}_{\mathrm{T}}<210 \mathrm{gBTEX} \mathrm{m}^{-3} \mathrm{~h}^{-1}$ the $\mathrm{RE}_{\mathrm{T}}$ was maintained consistently at $>80 \%$, irrespective of the $\mathrm{RH}$ conditions. However, the biofilter did not exhibit any marked difference in the critical ILR $\mathrm{R}_{\mathrm{T}}$ values, contrary to what was observed earlier for changes in EBRTs, despite the variation in RH from very low (30\%) to normal operational values of a conventional biofilter ( $>95 \%)$. This can be explained by the fact that some mineral medium was occasionally fed, twice a week, to the biofilter, as would also be done for full-scale systems. This allows maintaining the water content of the filter bed sufficiently high, avoiding any marked effect of the waste-gas relative humidity.

Concerning the removal of individual BTEp,m,o-X compounds, in the concentration range tested, T,E, and $m, o-X$ showed $>70 \%$ REs, compared to $\mathrm{B}$ and $p$-X whose REs were $<55 \%$ at all the tested $\mathrm{RH}$ conditions. The maximum $\mathrm{EC}_{\mathrm{T}}$ of the biofilter, at a $\mathrm{RH}$ of $65 \%$, was $244.2 \mathrm{~g} \mathrm{~m}^{-3} \mathrm{~h}^{-1}$, which is comparable to the maximum $\mathrm{EC}_{\mathrm{T}}$ value achieved in this study at an EBRT of $144 \mathrm{~s}$ with $>95 \% \mathrm{RH}$ ( Table 1). It is often recommended in the literature to pre-humidify the waste-gas to be treated in a biofilter, up to values exceeding 95\% RH. However, the present results show that this is not necessarily a prerequisite if water is sprinkled twice a week on top of the filter bed. The critical load 
would remain unchanged, although the EC will level off somewhat faster at the lowest $\mathrm{RH}$ reaching a lower $\mathrm{EC}_{\max }$ than at higher $\mathrm{RH}$. The reactors performance should not drop as long as the water content of the biofilter remains above $40 \%$. In case of fungal biofilters, this value could even be lower.

\subsection{Performance at different $\mathrm{pH}$}

The effect of filter bed $\mathrm{pH}$ was studied by continuously recirculating the nutrient medium at the desired $\mathrm{pH}(5.9,7.0$, and 4.9) over the filter bed at a trickling rate of $72 \mathrm{~mL} \min ^{-1}$. At $\mathrm{pH}$ 5.9, two G/L ratios were studied, i.e., 43 and 80.2, while the EBRTs were maintained at either 77.8 or $41.7 \mathrm{~s}$, respectively. Experiments at pH 7.0 and 4.9 were carried out for 33 and $24 \mathrm{~d}$, at $\mathrm{G} / \mathrm{L}$ ratios of 83.7 and 125.6, respectively ( Table 1). Although the biofilter operation now resembles that of a conventional biotrickling filter, by doing so the desired $\mathrm{pH}$ levels could continuously be maintained constant within the filter bed. Failure to do so would eventually lead to possible fluctuations of the filter bed's $\mathrm{pH}$ affecting the main goal of this experiment. Fig. 2a-f shows the 6 phases of biofilter operation at different $\mathrm{pH}$ conditions and the respective inlet concentrations and RE profiles of individual BTEp,m,o-X compounds, while Fig. $2 \mathrm{~g}$ shows the total BTEX concentrations and the corresponding $\mathrm{RE}_{\mathrm{T}}$ profiles. The concentrations of BTEp, $m, o-X$ during the first $20 \mathrm{~d}$ operation were as follow: $\mathrm{B}=0.2$ $3.7 \mathrm{~g} \mathrm{~m}^{-3}, \mathrm{~T}=0.08-1.1 \mathrm{~g} \mathrm{~m}^{-3}, \mathrm{E}=0.06-3.15 \mathrm{~g} \mathrm{~m}^{-3}, p-\mathrm{X}=0.07-1.9 \mathrm{~g} \mathrm{~m}^{-3}, m-\mathrm{X}=0.08-$ $2.9 \mathrm{~g} \mathrm{~m}^{-3}, o-\mathrm{X}=0.04-1.3 \mathrm{~g} \mathrm{~m}^{-3}$. From Fig. 2a-g it can be seen that, during the first $20 \mathrm{~d}$ of operation at $\mathrm{pH} 5.9$ and at a G/L ratio of 43 (EBRT - $77.8 \mathrm{~s}$ ), the removal of individual BTEX compounds varied widely. The values were as low as $<20 \%$ in the case of $\mathrm{B}$ and $p, o-\mathrm{X}$, while the removal of other VOCs (TEm-X) occasionally reached $>80 \%$. The $\mathrm{RE}_{\mathrm{T}}$ also fluctuated between $\sim 20 \%$ and $70 \%$ depending on the removal of individual compounds in the mixture ( Fig. 2g). The fluctuating removal profiles during the initial $20 \mathrm{~d}$ of operation can be attributed to the operating conditions of the biofilter, i.e., with a continuous trickling phase in order to maintain the filter bed $\mathrm{pH}$ constant, and the requirement of a re-acclimation phase in this mode of operation, or pollutant mass transfer limitations due to high BTEX concentrations. Between days 21 and 54 (pH: 5.9, EBRT: $41.7 \mathrm{~s}$ ) the concentrations of individual BTEX compounds were increased further in order to envisage the maximum performance of the biofilter. The total BTEX concentrations were thus varied from 0.56 to $12.1 \mathrm{~g} \mathrm{~m}^{-3}$, corresponding to $\mathrm{ILR}_{\mathrm{T}}$ ranging from 48.8 to $1051.3 \mathrm{gBTEX} \mathrm{m}^{-3} \mathrm{~h}^{-1}$; and a maximum $\mathrm{RE}_{\mathrm{T}}$ of $77 \%$ was noticed when the ILR $\mathrm{R}_{\mathrm{T}}$ were $<80 \mathrm{gBTEX} \mathrm{m}^{-3} \mathrm{~h}^{-1}$. At this stage the biofilter experienced clogging problems due to excess biomass growth on the perlite, leading to flooding conditions near the inlet of the biofilter (top-section). The biofilter was stopped for $\sim 2 \mathrm{~h}$ to drain the excess nutrient medium, and the packing was removed from the biofilter. $500 \mathrm{~mL}$ of fresh perlite was added to the original packing with biomass, and then reintroduced into the biofilter. After a brief shut-down period $(8 \mathrm{~h})$, the biofilter was started with an operating bed volume of $4.5 \mathrm{~L}$. The concentrations of individual BTEX were brought down to values $<2.5 \mathrm{~g} \mathrm{~m}^{-3}$, corresponding to total BTEX concentrations ranging from 0.2 to $9.8 \mathrm{~g} \mathrm{~m}^{-3}$, during the next phase of operation that was performed at a $\mathrm{pH}$ of 7.0. At an EBRT of $45 \mathrm{~s}$ (G/L ratio: 83.7) in this phase (days 55-74), the RE of individual VOCs, as well as the $\mathrm{RE}_{\mathrm{T}}$ increased significantly, despite subjecting the biofilter to ILR $_{\mathrm{T}}$ as high as $791.2 \mathrm{gBTEX} \mathrm{m}^{-3} \mathrm{~h}^{-1}$. The removal of individual VOCs, such as BTE, was $>80 \%$, although the removal of xylene isomers dropped occasionally to values $<70 \%$ depending on their concentrations in the mixture. During days $75-88$ (EBRT: $30 \mathrm{~s}$ ), for inlet BTEX concentrations varying between 0.2 and $6.08 \mathrm{~g} \mathrm{~m}^{-3}$, the 
$\mathrm{RE}_{\mathrm{T}}$ were maintained consistently at $>90 \%$. Regarding experiments at $\mathrm{pH} 4.9$ (days 89111), the concentration of individual BTEX were maintained at $<1.2 \mathrm{~g} \mathrm{~m}^{-3}$, corresponding to ILR $_{\mathrm{T}}$ ranging from 147.5 to $364.1 \mathrm{gBTEX} \mathrm{m}^{-3} \mathrm{~h}^{-1}$ at an EBRT of $45 \mathrm{~s}$, and from 181.2 to $232.8 \mathrm{gBTEX} \mathrm{m}^{-3} \mathrm{~h}^{-1}$ at an EBRT of $30 \mathrm{~s}$. In this concentration range, all VOCs were removed with more than $80 \%$ except benzene. Thus, for total BTEX concentrations $<4.5 \mathrm{~g} \mathrm{~m}^{-3}$, the $\mathrm{RE}_{\mathrm{T}}$ in this phase, at $\mathrm{pH}: 4.9$, ranged from 88 to $100 \%$.

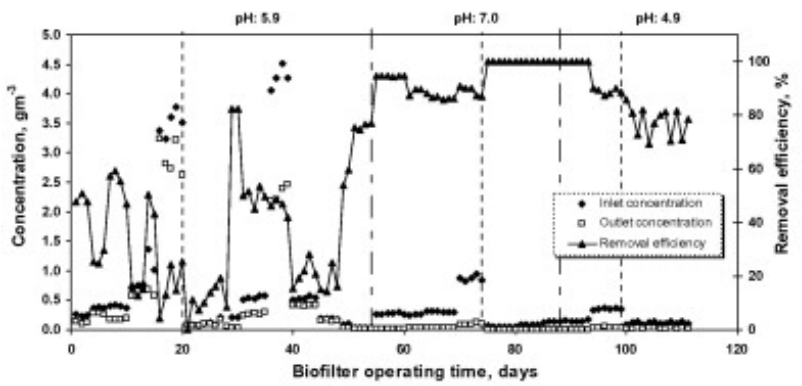

(a)

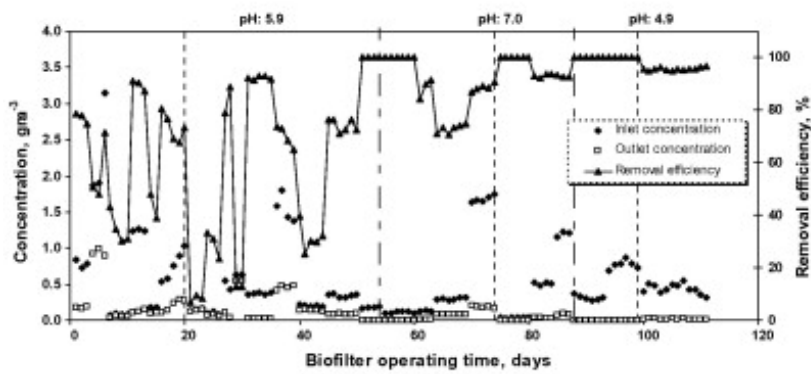

(c)

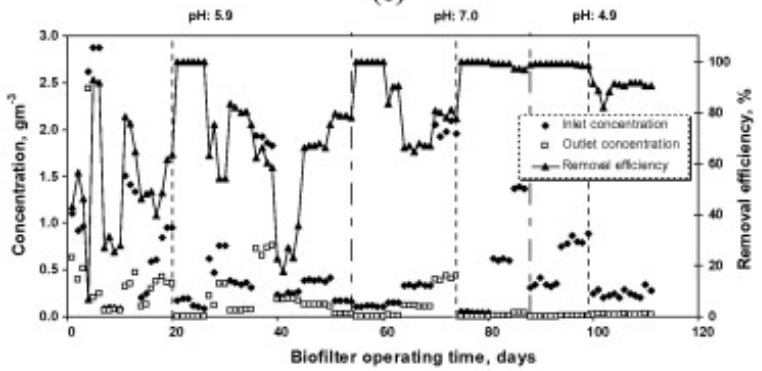

(e)

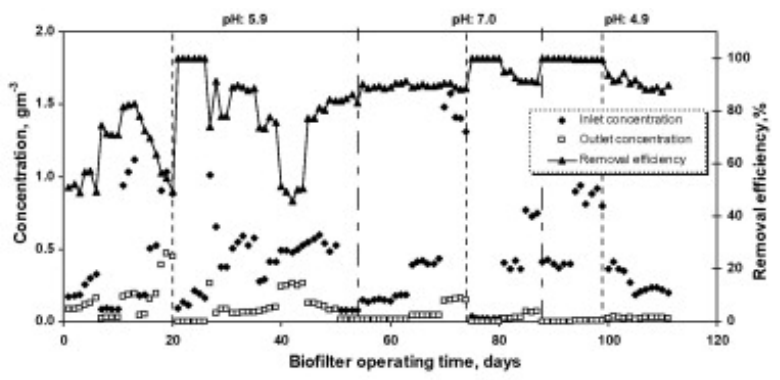

(b)

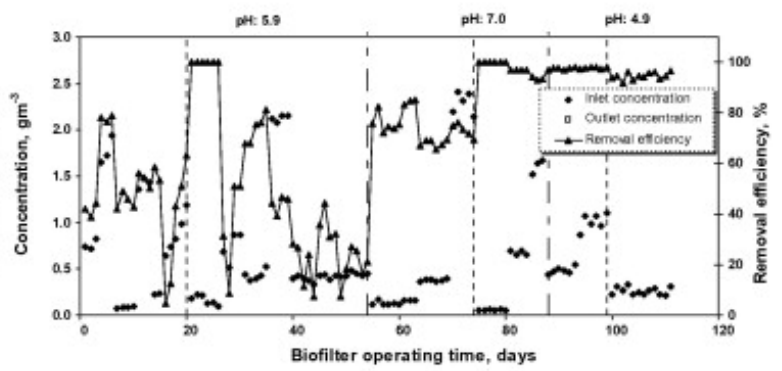

(d)

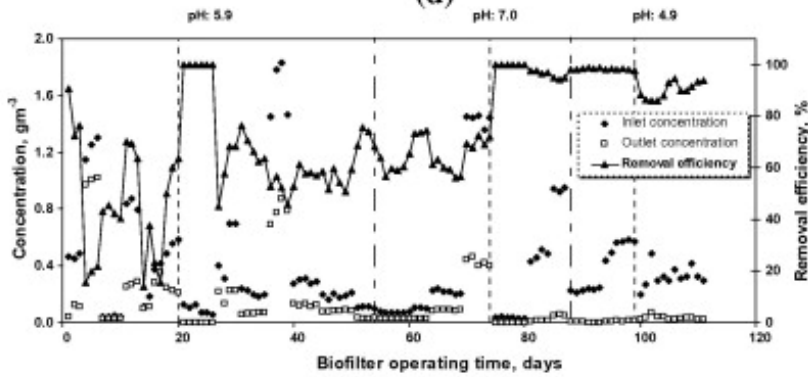

(f)

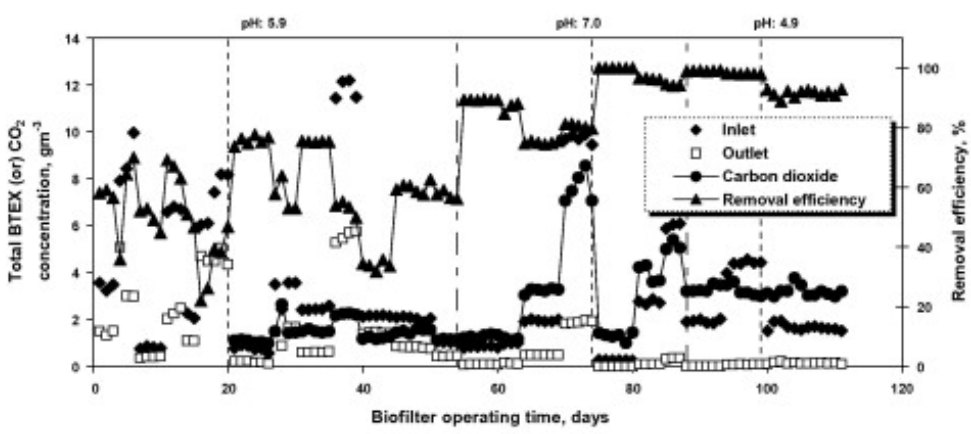

(g)

Fig. 2.

Individual BTEX concentration and removal profiles at different $\mathrm{pH}$ conditions; (a) benzene, (b) toluene, (c) ethylbenzene, (d) p-xylene, (e) m-xylene, (f) $o$ xylene, and (g) total BTEX concentrations and $\mathrm{RE}_{\mathrm{T}}$ profiles. 
Fig. 3a-c illustrates the effect of ILR of individual BTEX on the EC, while Fig. 3d compares the effect of total BTEX loading rates $\left(\mathrm{ILR}_{\mathrm{T}}\right)$ on the $\mathrm{EC}_{\mathrm{T}}$ of the biofilter, at different pHs. As evident from these figures, still higher EC could have been achieved for the individual VOCs at $\mathrm{pH} 7.0$ and 4.9 because near linear relationships between ILR and EC were noticed over all the range of tested ILRs. Among the BTEX compounds, ethylbenzene and $m$-xylene were removed better, reaching $\mathrm{EC}_{\max }$ of, respectively, 113 and $121 \mathrm{~g} \mathrm{~m}^{-3} \mathrm{~h}^{-1}$ at $\mathrm{pH}$ 5.9, and 135 and $187 \mathrm{~g} \mathrm{~m}^{-3} \mathrm{~h}^{-1}$ at $\mathrm{pH} 4.9$. The removal of benzene or xylenes has nearly always been reported to be less efficient by either bacteria or fungi in comparison with other benzene-pollutants ( Prenafeta-Boldu et al., 2002 and García-Peña et al., 2008). Regarding total BTEX loading to the biofilter, for $\mathrm{ILR}_{\mathrm{T}}<400 \mathrm{gBTEX} \mathrm{m}{ }^{-3} \mathrm{~h}^{-1}$, a near linear relationship was noticed for the EC profiles at $\mathrm{pH} 7.0$ and 4.9, reaching a maximum $\mathrm{EC}_{\mathrm{T}}$ of $687 \mathrm{~g} \mathrm{~m}^{-3} \mathrm{~h}^{-1}$ at an $\mathrm{ILR}_{\mathrm{T}}$ of 730.5 gBTEX $\mathrm{m}^{-3} \mathrm{~h}^{-1}$. The maximum $\mathrm{EC}_{\mathrm{T}}$ observed in this study is higher than most of the $\mathrm{EC}_{\max }$ values reported in the literature for the biofiltration of mixture of VOCs $\left(<10-340 \mathrm{~g} \mathrm{~m}^{-3} \mathrm{~h}^{-1}\right)$. Table 3 gives an overview of the sources of inoculum, the EBRTs tested, and the $\mathrm{EC}_{\max }$ achieved during the biotreatment of BTEX, TEX, TX, TXT, and MTBX mixtures in biofilters.
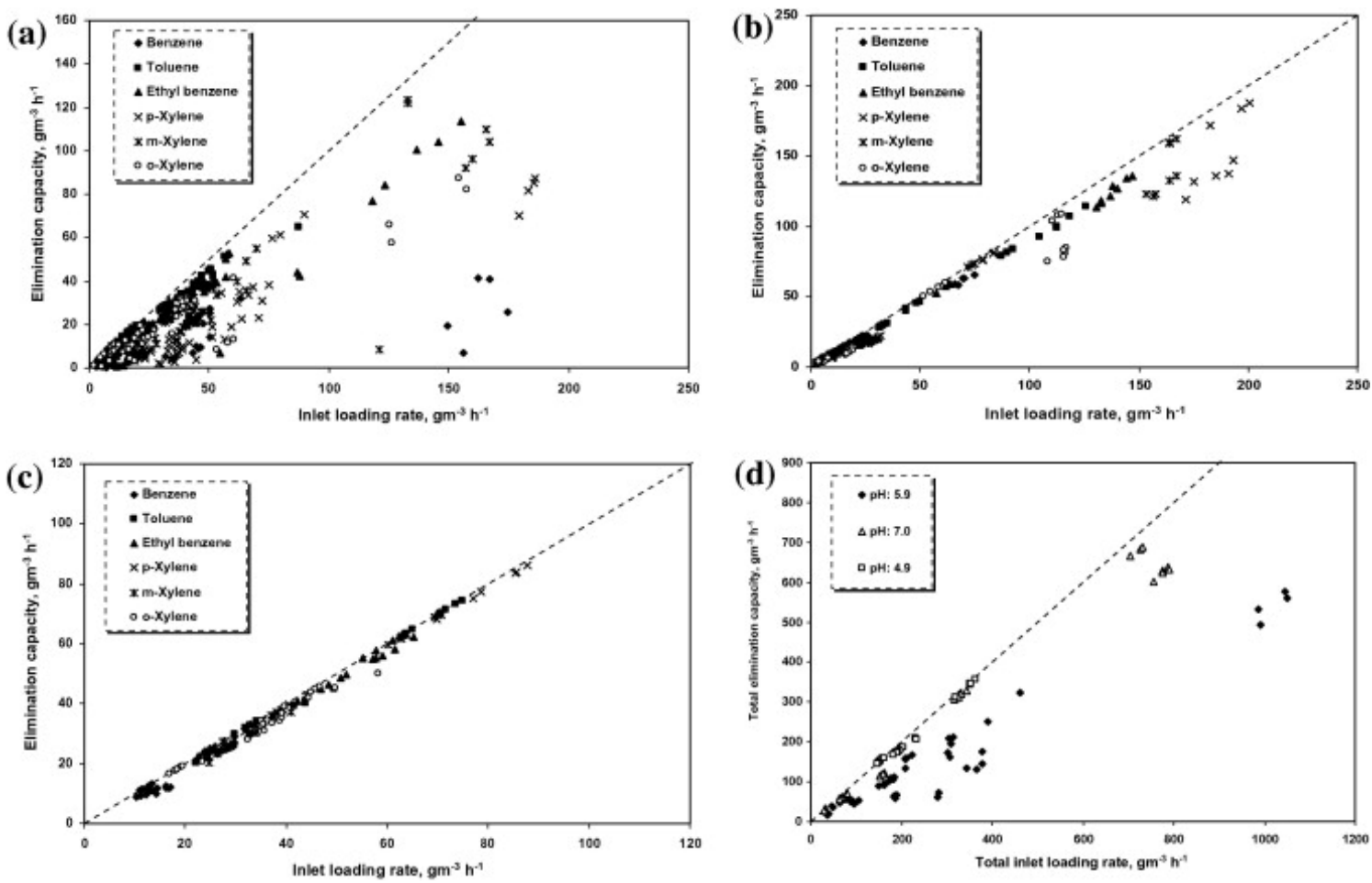

Fig. 3.

Effect of ILR on the EC of the biofilter for individual BTEX compounds at different $\mathrm{pH}$ conditions; (a) $\mathrm{pH}$ : 5.9, (b) $\mathrm{pH}$ : 7.0, (c) $\mathrm{pH}$ : 4.9, and (d) effect of $\mathrm{ILR}_{\mathrm{T}}$ on the $\mathrm{EC}_{\mathrm{T}}$ at different $\mathrm{pH}$ conditions. 
Table 3.

Literature information on BTEX removal in biofilters and typical maximum elimination capacity $\left(\mathrm{EC}_{\max }\right)$ values reported.

\begin{tabular}{|c|c|c|c|c|c|}
\hline Pollutants & Inoculum & \begin{tabular}{|l|} 
EBRT (or) \\
air velocity
\end{tabular} & $\begin{array}{l}\text { Packing } \\
\text { material }\end{array}$ & $\begin{array}{l}\begin{array}{l}E C_{\max } \\
\left(\mathrm{g} \mathrm{m}^{-3} \mathbf{h}^{-1}\right)\end{array} \\
\end{array}$ & Reference \\
\hline BTEX & $\begin{array}{l}\text { Paecilomyces } \\
\text { variotii }^{1}\end{array}$ & $1.7 \mathrm{~min}$ & Vermiculite & $110^{1_{*}}$ & \begin{tabular}{|l}
$\begin{array}{l}\text { García-Peña } \\
\text { et al. (2008) }\end{array}$ \\
\end{tabular} \\
\hline BTX & \begin{tabular}{|l|l|}
$\begin{array}{l}\text { Isolated bacterial } \\
\text { strains }\end{array}$ \\
\end{tabular} & $4.4 \mathrm{~min}$ & Dry peat moss & $40-45^{2 *}$ & 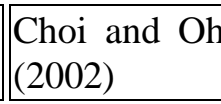 \\
\hline BTX & \begin{tabular}{|ll|}
\multicolumn{3}{|l|}{ Pseudomonas } \\
putida & strain \\
PPO1 $^{3}$ & \\
\end{tabular} & $40 \mathrm{~s}^{3 *}$ & Dry peat, perlite & $40-50$ & $\begin{array}{ll}\text { Oh } \\
\text { Bartha, } \\
(1997)\end{array}$ \\
\hline BTEX & $\mid \begin{array}{l}\text { Enriched } \\
\text { consortia }^{4}\end{array}$ & $0.5-3 \mathrm{~min}$ & \begin{tabular}{|l}
$\begin{array}{l}\text { Mature } \\
\text { composted pine } \\
\text { bark }\end{array}$ \\
\end{tabular} & $\mathrm{NA}^{4 *}$ & $\begin{array}{l}\text { Strauss et al. } \\
(2004)\end{array}$ \\
\hline TX & \begin{tabular}{|l|} 
Mixed microbial \\
population $^{5}$
\end{tabular} & $0.03 \mathrm{~m}^{3} \mathrm{~h}^{-1}$ & \begin{tabular}{|l|l|}
$\begin{array}{l}\text { Peat, bark and } \\
\text { wood }\end{array}$ & \\
\end{tabular} & $\sim 17^{5_{*}}$ & \begin{tabular}{|l} 
Marek et al. \\
$(1999)$
\end{tabular} \\
\hline BTX & Activated sludge ${ }^{6}$ & SV: $50 \mathrm{~h}^{-1}$ & \begin{tabular}{|l}
$\begin{array}{l}\text { Cubic } \\
\text { polyurethane } \\
\text { foam }\end{array}$ \\
\end{tabular} & $340^{6_{*}}$ & $\| \begin{array}{l}\text { Shim et al. } \\
(2006)\end{array}$ \\
\hline TXT & \begin{tabular}{|l|}
$\begin{array}{l}\text { Microbes present } \\
\text { in compost }^{7}\end{array}$ \\
\end{tabular} & $65 \mathrm{~s}$ & $\begin{array}{l}\text { Compost, } \\
\text { organic binder }\end{array}$ & $110^{7 *}$ & \begin{tabular}{|l} 
Delhoménie \\
et al. (2003)
\end{tabular} \\
\hline BTX & Activated sludge ${ }^{8}$ & $60 \mathrm{~s}$ & \begin{tabular}{|l|}
5 different types \\
of packing $^{\theta_{*}}$
\end{tabular} & 260 & $\begin{array}{lll}\text { Ortiz } & \text { et } & \text { al } \\
(2003) & \end{array}$ \\
\hline TEX & Activated sludge $^{9}$ & $\mid 16-120 \mathrm{~s}$ & Peat & $85^{9 *}$ & $\begin{array}{ll}\text { Gabaldon } & \text { et } \\
\text { al. (2006) }\end{array}$ \\
\hline MTBX & $\begin{array}{l}\text { Activated } \\
\text { sludge }^{10}\end{array}$ & $42-106 \mathrm{~s}$ & Coal & $184^{10_{*}}$ & \begin{tabular}{|l} 
Mathur and \\
Majumder \\
$(2008)$
\end{tabular} \\
\hline BTEX & Mixed culture ${ }^{11}$ & $1.2-2.3 \mathrm{~min}$ & $\begin{array}{l}\text { Compost, } \\
\text { baggase, GAC }\end{array}$ & $83.6^{11_{*}}$ & $\begin{array}{l}\text { Mathur et al. } \\
(2007)\end{array}$ \\
\hline ВТо-X & \begin{tabular}{||l} 
Enriched \\
microbial \\
consortium $^{12}$
\end{tabular} & $30-90 \mathrm{~s}$ & \begin{tabular}{|l|} 
Wheat bran, \\
redwood powder \\
and \\
diatomaceous \\
earth
\end{tabular} & $97.7^{12_{*}}$ & $\begin{array}{l}\text { Chen et al. } \\
(2010)\end{array}$ \\
\hline BTX & $\begin{array}{l}\text { Phanerochaete } \\
\text { chrysosporium }^{13}\end{array}$ & $\begin{array}{|ll|}\text { AV: } & 0.13 \\
0.53 & \mathrm{mh}^{-1} \\
\end{array}$ & \begin{tabular}{|l} 
Glass beads or \\
hydroballs
\end{tabular} & $<10^{13_{*}}$ & \begin{tabular}{|lrl}
$\begin{array}{l}\text { Oh et } \\
(1998)\end{array}$ & al. \\
\end{tabular} \\
\hline BTEX & Mixed culture ${ }^{14}$ & $90 \mathrm{~s}$ & Cork, GAC & \begin{tabular}{|ll} 
Cork- $\quad 86$ \\
GAC- \\
$67^{14_{*}}$ \\
\end{tabular} & \begin{tabular}{|l} 
Kwon and \\
Cho (2009)
\end{tabular} \\
\hline $\mathrm{T} p-\mathrm{X}$ & $\begin{array}{l}\text { Non-defined } \\
\text { mixed culture }\end{array}$ & $180 \mathrm{~s}$ & Small stones & $40^{15}$ & $\begin{array}{l}\text { Gallastegui et } \\
\text { al. (2011) }\end{array}$ \\
\hline TX & \begin{tabular}{|l} 
Mixture \\
bacteria $^{16}$
\end{tabular} & $78,102 \mathrm{~s}$ & Conditioned peat & $115^{16_{*}}$ & \begin{tabular}{|lll}
$\begin{array}{l}\text { Jorio } \\
(1998)\end{array}$ & et al. \\
\end{tabular} \\
\hline
\end{tabular}


Note: MTBX: methyl ethyl ketone (MEK), toluene, $n$-butyl acetate, and $o$ xylene; TXT: toluene, xylene and trimethylbenzene, TEX: toluene, ethylbenzene and xylene; GAC: granular activated carbon; SV: space velocity; EBRT: empty bed residence time; $\mathrm{AV}$ : air velocity; $\mathrm{RE}$ : removal efficiency; $\mathrm{EC}_{\max }$ : maximum elimination capacity; NA: not available.

Superscripts: Significant details and results, as reported by the authors. 1 - This culture was previously adapted to toluene in batch systems; $1^{*}-\mathrm{EC}_{\max }$ of $\mathrm{T}$ : $70 \mathrm{~g} \mathrm{C} \mathrm{m}^{-3} \mathrm{~h}^{-1}$, EB: $40 \mathrm{~g} \mathrm{C} \mathrm{m}^{-3} \mathrm{~h}^{-1}$, B: $10 \mathrm{~g} \mathrm{Cm}^{-3} \mathrm{~h}^{-1} ; 2$ - Source: wastewater treatment plant; $2^{*}$ - EC of $\mathrm{B}, \mathrm{T}, o-\mathrm{X}$, and $m, p$-X were 10.8, 14.2, 1.8, and $15.4 \mathrm{~g} \mathrm{~m}^{-3} \mathrm{~h}^{-1}$, respectively; 3 - Isolated from an industrial sludge that was enriched on equal parts of $\mathrm{B}, \mathrm{T}, p$-X; $3^{*}-$ In order to increase the $\mathrm{RE}_{\mathrm{T}}$ from $50 \%$ to $90 \%$, the authors suggested an EBRT of $80 \mathrm{~s} ; 4$ - Previously acclimated to toluene in a biofilter for over 4-months at an ILR of $32 \mathrm{~g} \mathrm{~m}^{-3} \mathrm{~h}^{-1} ; 4^{*}-$ Total BTEX load: $18.1 \mathrm{~g} \mathrm{~m}^{-3} \mathrm{~h}^{-1}$. The RE followed the order: $\mathrm{E}>\mathrm{B}>o-\mathrm{X}>m-\mathrm{X}>p$ $\mathrm{X} ; 5$ - Adaptation of soil micro-biota to BTEX; $5^{*}$ - Local EC monitored in the middle layer of the filter bed; 6 - BTX degradable culture; $6^{*}$ - The $\mathrm{EC}_{\max }$ for $\mathrm{B}$, $\mathrm{T}$, and $\mathrm{X}$ were 200,238 , and $400 \mathrm{~g} \mathrm{~m}^{-3} \mathrm{~h}^{-1} ; 7$ - Total culturable, the toluenespecific and the nitrifying bacterial counts were measured; $7^{*}$ - Biodegradability followed the order: T > X > T; 8 - Adapted to toluene and then to BTX vapours; $8^{*}$ - Peat, activated carbon, pine tree bark, Rashig glass rings and vermiculite; 9 - Activated sludge was acclimated for 2 months with TEX mixture in a reactor; 9* - Individual $\mathrm{EC}_{\max }$ of $\mathrm{T}, \mathrm{E}$, and $\mathrm{X}$ were 90,100 , and $65 \mathrm{~g} \mathrm{~m}^{-3} \mathrm{~h}^{-1} ; 10-$ Acclimated in nutrient medium containing $50 \mu \mathrm{L}$ of each of MTBX; $10^{*}-$ Maximum removal rates of MTBX were: 0.085, 0.033, 0.16, and $0.024 \mathrm{~g} \mathrm{~m}^{-3} \mathrm{~h}^{-1} ; 11$ - Microorganisms from previously operated biofilter, and identified as B. Sphaericus; $11^{*}-$ Nearly $100 \%$ BTEX was removed at ILR $_{\mathrm{T}}$ $<68 \mathrm{~g} \mathrm{~m}^{-3} \mathrm{~h}^{-1} ; 12$ - This consortium was grown on BTo-X compounds; $12^{*}-$ $\mathrm{EC}_{\max }$ at EBRTs of $90,60,45$, and $30 \mathrm{~s}$ were 55, 73, 81 and $97 \mathrm{~g} \mathrm{~m}^{-3} \mathrm{~h}^{-1} ; 13-$ $P$. chrysosporium was able to mineralize all BTX components simultaneously; $13^{*}-\mathrm{EC}_{\max }$ for $\mathrm{B}, \mathrm{T}$, and $\mathrm{X}$ were $2.75,0.77$, and $0.24 \mathrm{~g} \mathrm{~m}^{-3} \mathrm{~h}^{-1} ; 14-$ Microorganisms from public sewage was grown in toluene-saturated environment; $14^{*}$ - Degradation of benzene and xylene were poor compared to toluene; $15-\mathrm{EC}_{\max }$ for $p$-X and $\mathrm{T}$ were 26.5 , and $40.3 \mathrm{~g} \mathrm{~m}^{-3} \mathrm{~h}^{-1}$. The presence of $p$-X had an enhancing effect on the toluene removal efficiency; 16 Identified as Pseudomonas putida, Rhodococcus sp., and Arthrobacter paraffineus; $16^{*}-\mathrm{EC}_{\max }$ for $\mathrm{T}$ and $\mathrm{X}$ were 165 , and $66 \mathrm{~g} \mathrm{~m}^{-3} \mathrm{~h}^{-1}$.

\subsection{Carbon dioxide profiles in the biofilter}

The variation of $\mathrm{CO}_{2}$ production, $\mathrm{PCO}_{2}$, as a function of the $\mathrm{EC}_{\mathrm{T}}$ under different experimental conditions, i.e. , at different $\mathrm{RH}$ and $\mathrm{pH}$, was calculated. It was observed that the $\mathrm{PCO}_{2}$ values increased with an increase in the $\mathrm{EC}_{\mathrm{T}}$ of the biofilter, irrespective of the operational condition, and maximum $\mathrm{PCO}_{2}$ values reached $680 \mathrm{gCO}_{2} \mathrm{~m}^{-3} \mathrm{~h}^{-1}$ for the highest $\mathrm{ILR}_{\mathrm{T}}$ tested in the biofilter $\left(>700 \mathrm{gBTEX} \mathrm{m}^{-3} \mathrm{~h}^{-1}\right)$. The experimental data also reveal that the variation was nearly linear in all cases with a carbon dioxide yield $\left(\mathrm{PCO}_{2} / \mathrm{EC}_{\mathrm{T}}\right)$ by weight of 0.98 (RH experiments) and 0.91 ( $\mathrm{pH}$ experiments), respectively. This confirmed the mineralization of the individual BTEX compounds to $\mathrm{CO}_{2}$, water, and other biodegradation end-products. The carbon dioxide yield observed in this study is less than the expected carbon dioxide yield $(\sim 3.3)$ resulting from the 
stoichiometric equations for the complete mineralization of BTEX, when omitting biomass formation ( Chen et al., 2010 and Gallastegui et al., 2011). The discrepancies between theoretical and observed $\mathrm{CO}_{2}$ profiles are not unusual during continuous biofilter operation, especially when the biofilter is subjected to high loads of VOC mixtures. Some of the $\mathrm{CO}_{2}$ produced could have accumulated in the liquid-phase in the form of $\mathrm{HCO}_{3}^{-}, \mathrm{H}_{2} \mathrm{CO}_{3}$ and $\mathrm{CO}_{3}^{2-}$ or mineral acids could have formed as biodegradation end-products. However, to obtain the theoretical $\mathrm{CO}_{2}$ yield of $\sim 3.3$ for BTEX oxidation, the formulae of biomass is not considered. Thus, for instance, by taking into account the formulae of biomass as $\mathrm{C}_{5} \mathrm{H}_{7} \mathrm{NO}_{2}$ ( Kennes and Veiga, 2001) and ammonium chloride $\left(\mathrm{NH}_{4} \mathrm{Cl}\right)$ as the nitrogen source in the mineral medium, the stoichiometric equation for complete mineralization of toluene can be written as follows:

$\mathrm{C}_{7} \mathrm{H}_{8}+4 \mathrm{O}_{2}+\mathrm{NH}_{4} \mathrm{Cl} \rightarrow 2 \mathrm{CO}_{2}+\mathrm{C}_{5} \mathrm{H}_{7} \mathrm{NO}_{2}+\mathrm{HCl}+2 \mathrm{H}_{2} \mathrm{O}$

Similar stoichiometric equations can be derived for other VOCs used in this work.

\subsection{Performance under shock-load conditions}

After the completion of steady-state experiments at different EBRTs, the next step was to evaluate the biofilter's performance under shock-loading conditions (Table 2). As seen in Fig. 4a-c, prior to the first shock-load, the total inlet BTEX concentrations were held constant at $0.5 \mathrm{~g} \mathrm{~m}^{-3}$ for 2 days in order to achieve high BTEX removals $(\geqslant 97 \%$ $\mathrm{RE}_{\mathrm{T}}$ ). After that, the inlet concentrations of individual $\mathrm{B}, \mathrm{T}, \mathrm{E}, p-\mathrm{X}, m-\mathrm{X}$ and $o$-X were increased from 0.07 to $3.92,0.14$ to $1.3,0.06$ to $1.25,0.09$ to $2.3,0.08$ to 1.43 , and 0.03 to $1.06 \mathrm{~g} \mathrm{~m}^{-3}$, respectively, corresponding to a total BTEX concentration of $9.8 \mathrm{~g} \mathrm{~m}^{-3}$ on the 3rd day. Thus, by increasing the concentrations of individual VOCs, the ILR $_{T}$ also increased from about $\sim 50$ to 850 gBTEX m$~_{-3} \mathrm{~h}^{-1}$ ( Fig. 4c). The response of the biofilter was fast, as seen from the sudden drop in $\mathrm{RE}_{\mathrm{T}}$ from $90 \%$ to $35 \%$. However, an increase in the $I_{L R}$ from 50 to $850 \mathrm{~g} \mathrm{~m}^{-3} \mathrm{~h}^{-1}$ also exhibited a marked increase in the $\mathrm{EC}_{\mathrm{T}}$ of the biofilter, from 44 to $322 \mathrm{~g} \mathrm{~m}^{-3} \mathrm{~h}^{-1}$. During this shock-load, the RE of individual B, T, E, $p-\mathrm{X}, m-\mathrm{X}$ and $o-\mathrm{X}$ decreased to REs $<20 \%$ for benzene and $o-$ xylene, $\sim 50 \%$ for ethylbenzene and $m$-xylene, and $\sim 45 \%$ for both toluene and $p$-xylene, respectively. This high shock-load was applied to the biofilter for the next $4 \mathrm{~d}$, and when pre-shock conditions were restored, the $\mathrm{RE}_{\mathrm{T}}$ of the biofilter also increased to $>90 \%$, thus stabilizing the $\mathrm{EC}_{\mathrm{T}}$ of the biofilter at $46 \mathrm{~g} \mathrm{~m}^{-3} \mathrm{~h}^{-1}$ at an $\operatorname{ILR}_{\mathrm{T}}$ of $50 \mathrm{~g} \mathrm{~m}^{-3} \mathrm{~h}^{-1}$. When a second, lower, shock-load of $320 \mathrm{gBTEX} \mathrm{m}^{-3} \mathrm{~h}^{-1}$ was applied on the 11th day, the total BTEX removal $\left(\mathrm{RE}_{\mathrm{T}}\right)$ dropped only by $30 \%$. During this shockloading step, the removal of individual VOCs were as follows: B-28\%, T-63\%, E-78\%, $p-\mathrm{X}-45 \%, m-\mathrm{X}-76 \%$, and $o-\mathrm{X}-44 \%$. Anew, original removal performances were also reestablished quickly in the biofilter when the $\operatorname{ILR}_{T}$ was lowered. This shows the sensitivity of the biofilter to changes in loading rate patterns. An increase in the ILR $_{T}$ from 50 to $320 \mathrm{~g} \mathrm{~m}^{-3} \mathrm{~h}^{-1}$ also increased the $\mathrm{EC}_{\mathrm{T}}$ of the biofilter from 45 to 199 gBTEX $\mathrm{m}^{-3} \mathrm{~h}^{-1}$. The maximum $\mathrm{EC}_{\mathrm{T}}$ achieved under such high successive shockloads in the biofilter was $322 \mathrm{~g} \mathrm{~m}^{-3} \mathrm{~h}^{-1}$ at the highest overload tested, with $38 \%$ BTEX removal ( Fig. 4c). The $\mathrm{EC}_{\max }$ of individual B, T, E, $p-\mathrm{X}, m-\mathrm{X}$ and $o$-X compounds were as follows: 73.7, 71.6, 63.3, 105.6, 61.6, and $20.9 \mathrm{~g} \mathrm{~m}^{-3} \mathrm{~h}^{-1}$, respectively. The biofilter performance during successive shock-loads was limited by the biological reaction, a problem often encountered in biological waste-gas treatment systems treating hydrophobic VOCs like BTEX at high concentrations ( Kennes and Veiga, 
2001 and Kennes et al., 2009b). During large transient operations, either the mass transfer capacity or the reaction capacity of the initial sections of the bed is exceeded and contaminants move into the next sections where the microbial populations and reaction capacities are low and contaminant breakthrough may occur ( Wright et al., 2005).
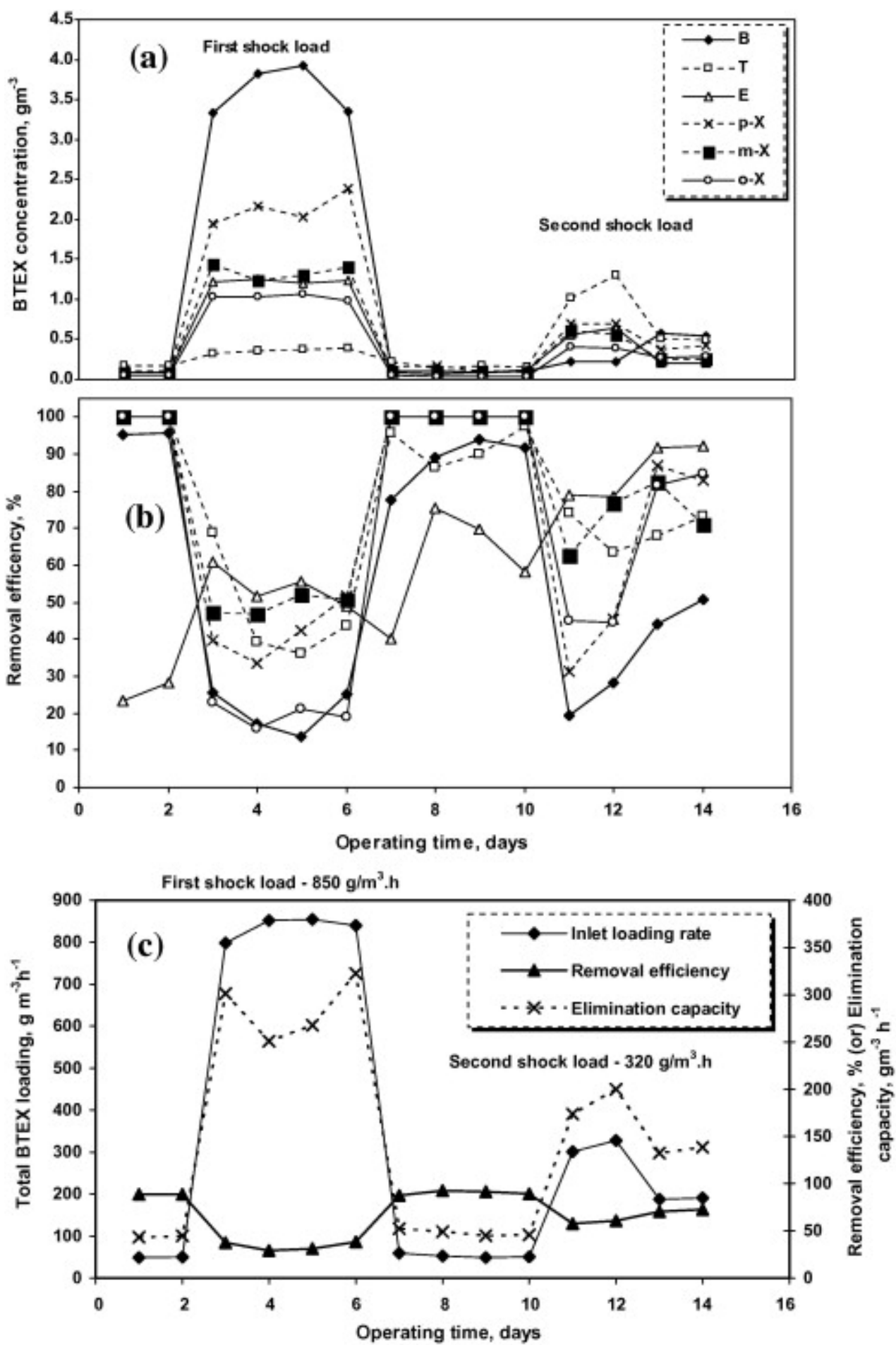

Fig. 4. Response of fungi-dominant biofilter to successive shock-loads: (a) individual BTEX concentration profiles, (b) BTEX removal efficiency profiles, and (c) total BTEX removal and elimination capacity profiles as a function of total BTEX loading rate. 


\subsection{Performance under shut-down and re-start operations}

Fig. 5a-c shows the individual BTEX concentrations, RE profiles, $\operatorname{ILR}_{T}$ and $\mathrm{EC}_{\mathrm{T}}$ profiles in the biofilter during short-and long-term shut-downs. In order to prevent the microorganisms in the biofilter from experiencing any substrate inhibition effects, the individual maximum BTEX concentrations tested during these experiments $\left(<0.72 \mathrm{~g} \mathrm{~m}^{-3}\right)$ were much lower than the concentration levels of BTEX tested during shock-load experiments (Table 2). During short-term shut-downs, BTEX was not fed to the biofilter, thus depriving the biomass of the essential carbon source; and during longterm shut-downs neither the pollutant nor air was passed through the system, and nutrients were added only during the re-start phase. Under such conditions, the microorganisms could survive in the bioreactor for a limited period of time by scavenging the remaining organic matter and nutrients adsorbed onto the packing and converting them into useful energy and cellular material. Such temporary starvation would place the biomass under stress and decrease their enzyme activities. Prior to the first shut-down period, the ILR of each individual BTEX compounds was $<50 \mathrm{~g} \mathrm{~m}^{-3} \mathrm{~h}^{-1}$, and the corresponding REs were 50, 85, 95, 79, 77 and $66 \%$ for $\mathrm{B}, \mathrm{T}, \mathrm{E}$, $p$-X, $m-\mathrm{X}$ and $o-\mathrm{X}$, respectively, at a total BTEX concentration of $2.9 \mathrm{~g} \mathrm{~m}^{-3}$. From Fig. $5 c$, during the re-start phase (day 8), it is evident that the biofilter was able to maintain its RE after a short-term shut-down reaching a maximum $\mathrm{EC}_{\mathrm{T}}$ of $200 \mathrm{~g} \mathrm{~m}^{-3} \mathrm{~h}^{-1}$ with about $75 \% \mathrm{RE}_{\mathrm{T}}$. However, after a long-term shut-down, even when the total inlet BTEX concentration was reduced to $1 \mathrm{~g} \mathrm{~m}^{-3}$ in comparison to the previous value of $2.9 \mathrm{~g} \mathrm{~m}^{-3}$, the RE of the biofilter dropped by almost $25 \%$. During continuous operation at the same inlet concentration after re-start, the biofilter was able to recover and reach again $\sim 75 \%$ $\mathrm{RE}_{\mathrm{T}}$ in about $4 \mathrm{~d}$. As described earlier, re-acclimation times during shut-down and restart have shown to vary depending on the process conditions and microbial activities. Elmrini et al. (2001) reported that a re-acclimation period of $8 \mathrm{~d}$ was needed for a biofilter handling toluene vapors to recover its original state, after a prolonged shutdown period of 8 months. In this study, although the removal of benzene and ethylbenzene remained unaffected during the second re-start phase, the RE of T, $p$-X, $m$-X and $o$-X dropped from $85 \%$ to $76 \%, 79 \%$ to $27 \%, 77 \%$ to $56 \%$, and $66 \%$ to $56 \%$, respectively ( Fig. 5b). During extended shut-down periods, the nutrients in the biofilter would have maintained the activity of the biomass and stability of the biofilter. During this experimental phase, the $\mathrm{EC}_{\max }$ of individual $\mathrm{B}, \mathrm{T}, \mathrm{E}, p-\mathrm{X}, m-\mathrm{X}$ and $o$-X compounds were as follows: $32.5,39.8,47.9,53.2,28.3$, and $14.5 \mathrm{~g} \mathrm{~m}^{-3} \mathrm{~h}^{-1}$, respectively. 
Fig. 5.
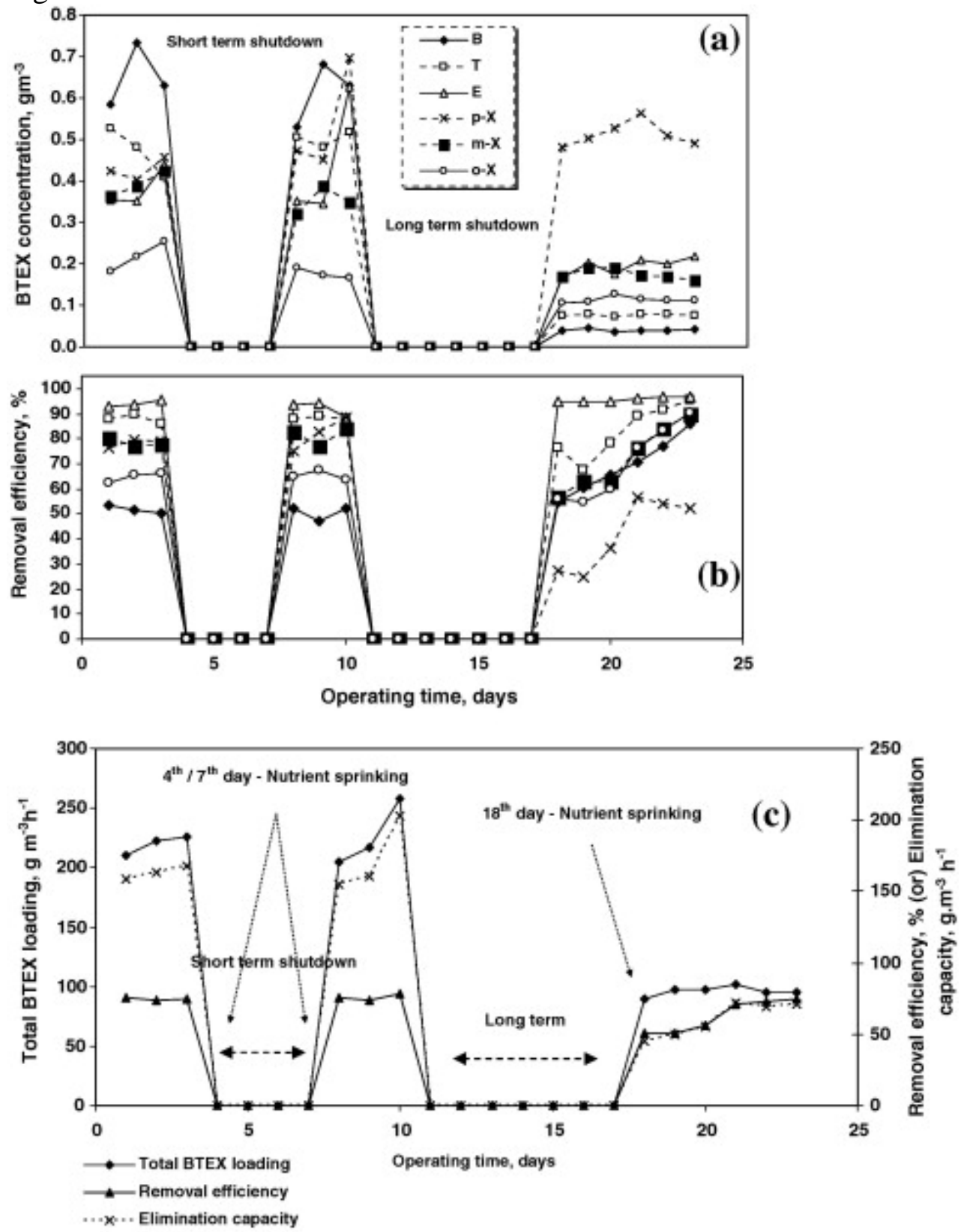

Response of fungi-dominant biofilter to shut-down and re-start operations: (a) individual BTEX concentration profiles, (b) BTEX removal efficiency profiles, and (c) total BTEX removal and elimination capacity profiles as a function of total BTEX loading rate.

\subsection{Substrate stratification in the biofilter during steady-state operations}

Substrate stratification profiles were measured under the following conditions: $\mathrm{pH}=7.0$, EBRT $=45 \mathrm{~s}, \mathrm{~B}=0.08 \mathrm{~g} \mathrm{~m}^{-3}, \mathrm{~T}=0.4 \mathrm{~g} \mathrm{~m}^{-3}, \mathrm{E}=1 \mathrm{~g} \mathrm{~m}^{-3}, p-\mathrm{X}=1.3 \mathrm{~g} \mathrm{~m}^{-3}, \mathrm{~m}-$ $\mathrm{X}=1.2 \mathrm{~g} \mathrm{~m}^{-3}$ and $o-\mathrm{X}=0.9 \mathrm{~g} \mathrm{~m}^{-3}$, respectively, corresponding to an $\mathrm{ILR}_{\mathrm{T}}$ of 394 gBTEX $\mathrm{m}^{-3} \mathrm{~h}^{-1}$ ( Fig. 6). T, E, $m$-X and $o$-X were removed better $(\sim 50 \%)$ in the lower section of the filter bed, while $\mathrm{B}$ and $p$-X were removed only in the upper section of the filter bed. The REs of T, E, $m$-X and $o$-X were higher than $75 \%$, while the removal of $\mathrm{B}$ and $p$-X was less than $40 \%$. The differences in the removal profiles could 
be due to the different microbial species developing in the biofilter during its long-term operation, their specific activities, and the metabolic pathways utilized by the dominant strains involved in BTEX degradation. Apparently, changes in experimental conditions (EBRT, concentrations of BTEX, RH, $\mathrm{pH}$, and transient-state studies) could affect the composition of the process culture and both the rate of mass accumulation and the rate of pollutant degradation ( Heitzer et al., 1991). The results from this study showed the versatility of the fungi-dominant biofilter to handle both neutral and mildly acidic $\mathrm{pH}$ conditions, reaching high $\mathrm{EC}_{\mathrm{T}}$ and $\mathrm{RE}_{\mathrm{T}}$ under long-term steady and transient-state operations.

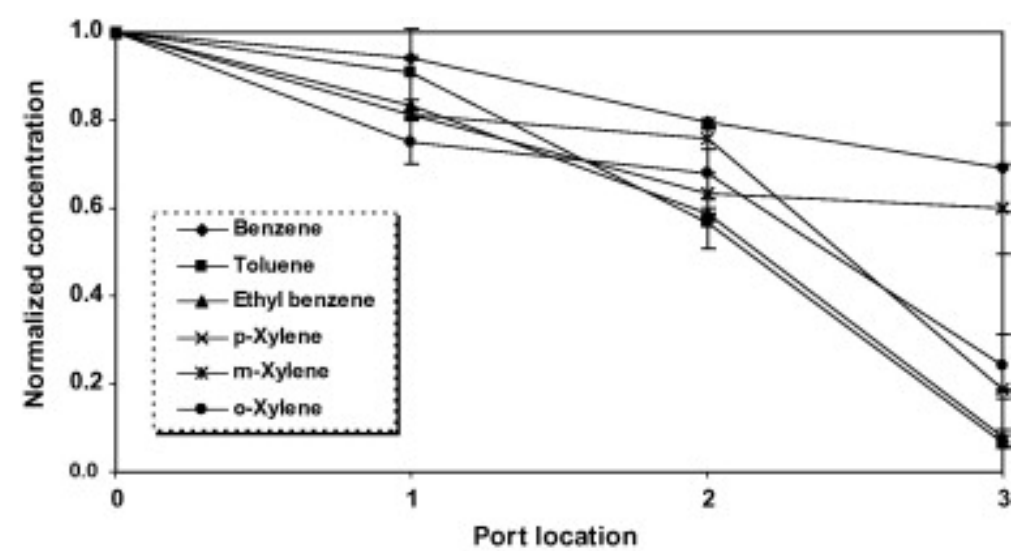

Fig. 6.

Substrate stratification profiles in the biofilter.

\section{Conclusions}

The critical $\mathrm{ILR}_{\mathrm{T}}$ to achieve $>90 \% \mathrm{RE}_{\mathrm{T}}$ was found to drop at lower EBRTs. The results showed that it is not a pre-requisite to humidify the incoming waste-gas to $>95 \% \mathrm{RH}$, if water is sprinkled twice a week on top of the filter bed. When the biofilter was operated at a constant $\mathrm{pH}$ (7.0/4.9), for $\mathrm{ILR}_{\mathrm{T}}<400 \mathrm{gBTEX} \mathrm{m}^{-3} \mathrm{~h}^{-1}$, a near-linear relationship was noticed for $\mathrm{EC}_{\mathrm{T}}$ profiles. The biofilter was sensitive to successive shock-loads, and could easily recover its performance after intermittent short and long-term shut-down operations, and such transient-state conditions did not affect all different BTEX compounds in a similar way.

\section{Acknowledgements}

The authors thank the Ministry of Education and Science (CTM2004-00427/TECNO and SB-2004-0135), European FEDER funds, and the Ministry of Science and Innovation (JCI-2008-0385) for financial support and post-doctoral research contracts.

\section{References}

H.N. Abubackar, M.C. Veiga, C. Kennes

Biological conversion of carbon monoxide-rich syngas or waste gases to bioethanol

Biofpr, 5 (2011), pp. 93-114 
A.R. Bielefeldt, H.D. Stensel

Modeling competitive inhibition effects during biodegradation of BTEX mixtures

Water Res., 33 (1999), pp. 707-714

J.M. Chen, R.Y. Zhu, W.B. Yang, L.L. Zhang

Treatment of a BTo-X-contaminated gas stream with a biotrickling filter inoculated with microbes bound to a wheat bran/red wood powder/diatomaceous earth carrier

Bioresour. Technol., 101 (2010), pp. 8067-8073

S.-C. Choi, Y.-S. Oh

Simultaneous removal of benzene, toluene and xylenes mixture by a constructed microbial consortium during biofiltration

Biotechnol. Lett., 24 (2002), pp. 1269-1275

M.C. Delhoménie, L. Bibeau, J. Gendron, R. Brzezinski, M. Heitz

Degradation of toluene, xylene, and trimethylbenzene vapors by biofiltration: a comparison

J. Air Waste Manage. Assoc., 53 (2003), pp. 217-226

H. Elmrini, F. Kerdouss, H. Jorio, M. Heitz

Biofiltration of air contaminated with toluene

Environ. Technol., 22 (2001), pp. 927-940

C. Gabaldon, V. Martinez-Soria, M. Martin, P. Marzal, J.M. Penya-Roja, J. Alvarez-Hornos

Removal of TEX vapours from air in a peat biofilter: influence of inlet concentration and inlet load

J. Chem. Technol. Biotechnol., 81 (2006), pp. 322-328

G. Gallastegui, A.Á. Ramirez, A. Elías, J.P. Jones, M. Heitz

Performance and macrokinetic analysis of biofiltration of toluene and $p$ xylene mixtures in a conventional biofilter packed with inert material

Bioresour. Technol., 102 (2011), pp. 7657-7665

I. García-Peña, I. Ortiz, S. Hernández, S. Revah

Biofiltration of BTEX by the fungus Paecilomyces variotii

Int. Biodeter. Biodegrad., 62 (2008), pp. 442-447

A. Heitzer, H.P.E. Kohler, P. Reichert, G. Hamer

Utility of phenomenological models for describing temperature dependence of bacterial growth

Appl. Environ. Microbiol., 57 (1991), pp. 2656-2665

H. Jorio, K. Kiared, R. Brzezinski, A. Leroux, G. Viel, M. Heitz

Treatment of air polluted with high concentrations of toluene and xylene in a pilot-scale biofilter

J. Chem. Technol. Biotechnol., 73 (1998), pp. 183-196 
H. Jorio, Y. Jin, H. Elmrini, J. Nikiema, R. Brzezinski, M. Heitz

Treatment of VOCs in biofilters inoculated with fungi and microbial consortium

Environ. Technol., 30 (2009), pp. 477-485

C. Kennes, H.H.J. Cox, H.J. Doddema, W. Harder

Design and performance of biofilters for the removal of alkylbenzene vapours

J. Chem. Technol. Biotechnol., 66 (1996), pp. 300-304

C. Kennes, E.R. Rene, M.C. Veiga

Bioprocesses for air pollution control

J. Chem. Technol. Biotechnol., 84 (2009), pp. 1419-1436

C. Kennes, M. Montes, M.E. López, M.C. Veiga

Waste gas treatment in bioreactors: environmental engineering aspects

Can. J. Civil Eng., 36 (2009), pp. 1887-1894

C. Kennes, M.C. Veiga

Conventional biofilters

C. Kennes, M.C. Veiga (Eds.), Bioreactors for Waste Gas Treatment, Kluwer Academic Publishers, Dordrecht, The Netherlands (2001), pp. 47-98 Chem. Eng. J., 157 (2010), pp. 339-347

Y.S. Oh, Z. Shareefdeen, B.C. Baltzis, R. Bartha

Interactions between benzene, toluene, and p-xylene (BTX) during their biodegradation

Biotechnol. Bioeng., 44 (1994), pp. 533-538

Y.-S. Oh, R. Bartha

Construction of a bacterial consortium for the biofiltration of benzene, toluene and xylene emissions

World J. Microbiol. Biotechnol., 13 (1997), pp. 627-632

Y.-S. Oh, S.-C. Choi, Y.-K. Kim

Degradation of gaseous BTX by biofiltration with Phanerochaete chrysosporium

J. Microbiol., 36 (1998), pp. 34-38

I. Ortiz, S. Revah, R. Auria

Effects of packing material on the biofiltration of benzene, toluene and xylene (BTX) vapors

Environ. Technol., 24 (2003), pp. 265-275

F.X. Prenafeta-Boldu, J. Vervoort, J.T.C. Grotenhuis, J.W. van Groenestijn Substrate interactions during the biodegradation of benzene, toluene, ethylbenzene, and xylene (BTEX) hydrocarbons by the fungus Cladophialophora sp. Strain T1

Appl. Environ. Microbiol., 68 (2002), pp. 2660-2665 
B. Qi, W.M. Moe

Performance of low-pH biofilters treating a paint solvent mixture: continuous and intermittent loading

J. Hazard. Mater., 135 (2006), pp. 303-310

C. Seignez, N. Adler, C. Thoeni, M. Stettler, P. Péringer, C. Holliger

Steady-state and transient-state performance of a biotrickling filter treating chlorobenzene-containing waste gas

Appl. Microbiol. Biotechnol., 65 (2004), pp. 33-37

E.-H. Shim, J. Kim, K.-S. Cho, H.W. Ryu

Biofiltration and inhibitory interactions of gaseous benzene, toluene, xylene and methyl tert-butyl ether

Environ. Sci. Technol., 40 (2006), pp. 3089-3094

J.M. Strauss, K.J. Riedel, C.A. du Plessis

Mesophilic and thermophilic BTEX substrate interactions for a tolueneacclimated biofilter

Appl. Microbiol. Biotechnol., 64 (2004), pp. 855-861

W.F. Wright, E.D. Schroeder, D.P.Y. Chang

Regular transient loading response in a vapor-phase flow-direction-switching biofilter

J. Environ. Eng., 131 (2005), pp. 1649-1658 